\title{
Familial isolated pituitary adenoma
}

INSERM

\section{Source}

INSERM. (1999). Orphanet: an online rare disease and orphan drug data base. Familial isolated pituitary adenoma. ORPHA:314777

A rare, genetic endocrine tumor characterized by variable clinical manifestations, resulting from the tumor size, excess hormone secretion or lack of hormone secretion. Tumor can be growth hormone-secreting, prolactin-secreting, growth hormone and prolactin co-secreting, and non-functioning pituitary adenomas. In rare cases, adenomas secrete TSH or ACTH. Within the same family, both same or different type of pituitary adenoma scan be present. 